\title{
Response of orthopterans to macroclimate changes: A 15-year case study in Central European humid grasslands
}

\author{
Zoltán Kenyeres', Gábor Takács², Norbert Bauer³
}

1 Acrida Conservational Research L.P., Tapolca 8300, Hungary.

2 Fertő-Hanság National Park Directorate, Sarród 9435, Hungary.

3 Department of Botany, Hungarian Natural History Museum, Budapest 1087, Hungary.

Corresponding author: Zoltán Kenyeres (kenyeres@acridabt.hu)

Academic editor: Maria-Marta Cigliano | Received 26 February 2019 | Accepted 29 May 2019 | Published 2 October 2019

http://zoobank.org/39E596D1-EFFF-4E9E-80FA-1E5C94DE31A5

Citation: Kenyeres Z, Takács G, Bauer N (2019) Response of orthopterans to macroclimate changes: A 15-year case study in Central European humid grasslands. Journal of Orthoptera Research 28(2): 187-193. https://doi.org/10.3897/jor.28.34102

\begin{abstract}
Orthoptera is a good indicator taxon of macroclimate changes. In our case study, we analyzed data of orthopterans, vegetation, and macroclimate collected yearly from 2002 through 2017 in Central European humid grasslands. During the study period, the annual mean temperature increased, while the relative abundance of moderately hygrophilic orthopteran species decreased significantly. On the other hand, the species richness and diversity of the assemblages increased due, mostly, to an increase of graminicole/thermophilic species. According to our results, the conservation of the hygrophilic orthopteran assemblages of Central European humid grasslands under global warming can only be ensured by adequate land management, which can at least mitigate the effects of climate change resulting in the warming and drying of humid habitats.
\end{abstract}

\section{Keywords}

climate change, Hungary, indicator, landscape management, monitoring, species richness

\section{Introduction}

Global climate change has a significant impact on insect populations and assemblages, both directly (in terms of temperature, precipitation, and seasonal changes) and indirectly (changes in vegetation productivity and quality characteristics, presence and spread of predators and pathogenic organisms) (Ryrholm 2001, Lightfoot 2006, Menéndez 2007). Orthopterans seem to be a good indicator for the monitoring of macroclimate changes, as their distribution, density, and assemblage structure are mostly determined by climatic conditions (Dreux 1962, Wingerden et al. 1992, Rácz et al. 1994, Guido and Chemini 2000, Squitier and Capinera 2002, Gardiner and Hassall 2009, Buri et al. 2013, Kenyeres et al. 2018). The mild effects of global climate change include variations in the phenological characteristics of the orthopteran species. According to the laboratory test results of Fielding and Defoliart (2010), in the cases of Melanoplus borealis (Fieber) and Melanoplus sanguinipes (Fabricius) a temperature increase of 2,3 , and $4{ }^{\circ} \mathrm{C}$ results in earlier hatching by 3, 5, and 7 days, respectively. This phe- nomenon was also observed in Hungary between 1958 and 2009: the hatching of early species such as Isophya costata, Isophya stysi, Isophya kraussii, and Isophya camptoxypha, shifted earlier and earlier at a rate of 2-3 days/decade, due to the increasing spring mean temperature (Szabó et al. 2014).

Another important phenomenon resulting from global warming is the change in the area boundary of the Orthoptera species according to their cold tolerance (Uvarov 1931, Burton 2001). European species were observed to be expanding to the north due to global warming including, among others, Phaneroptera falcata and Phaneroptera nana (Kočárek et al. 2008), Ruspolia nitidula, Mecostethus parapleurus (Holuša et al. 2007) and Roeseliana roeselii (Gardiner 2009, Wissmann et al. 2009). The results of the impact of climate change on density of orthopterans are contradictory; there are some localities where an increase has been found while in others a decrease in density was observed (Bale et al. 2002, O'Neill et al. 2008, Laws and Belovsky 2010). This may be due to the locality-specific reaction of insects to climate change influenced by several circumstances of the habitat (e.g., altitude), nutrition (e.g., polyphagous vs. monophagous) and climatic requirements of the dominant species (Bale et al. 2002). Flightless, habitat-specialist species with a restricted area are particularly vulnerable to the effects of climate change. Their yearly population size, in many cases, responds very sensitively to some climate parameters (Kenyeres et al. 2018).

In the case of European species, climate change, although to a negligible extent when compared to the above, also influences the composition of the orthopteran assemblages through the increase in the chances of survival of the species that overwinter in an imago state (Kiritani 2006).

According to our earlier experiences gained in various regions of Central Europe, the impact of climate change on the orthopteran assemblages is really pronounced in humid grassland habitats (Kenyeres and Cservenka 2014). In this case study, we analyzed the data of orthopterans, vegetation, and macroclimate collected yearly between 2002 and 2017 under the monitoring program of the Fertö-Hanság National Park Directorate. Our main questions included: 1) What changes can be seen in 
the relative abundance of different life forms and eco-types over the 15-year period? 2) Can changes be detected in the relative abundance of species? 3) Is it possible to show relationships between the diversity parameters of orthopteran assemblages and parameters of the macroclimate? We hypothesized that changes in macroclimate (increasing temperature and decreasing precipitation) may result in an increase of thermophilic species and in a decrease of hygrophilic species.

\section{Material and methods}

Study area. - The study area (240 ha) (Fig. 1) belongs to the Hanság mesoregion of the Kisalföld macroregion. It is located at an altitude of $114 \mathrm{~m}$ a.s.l. and is characterized by large flatlands.

The potential vegetation of Hanság, having previously had hydrological connections with Lake Fertő, which is $30 \mathrm{~km}$ away, is moorlands, fens, and marshlands. The drainage of the Hanság area started with the Romans, but the recent hydrological conditions are the result of interventions carried out in the last 100 years. At present, the natural vegetation of the region is restricted to some patches covered by large, mesic grasslands, mosaiced and surrounded by forests, scrubs, and tree plantations. The study area is dominated by intrazonal bog and fen soils. The level of the groundwater is permanently around $1 \mathrm{~m}$. Turf resulting from loosening organic material is about half a meter. The average total duration of annual insolation in the region is 1,900 hours. Mean annual temperature is around $10.1^{\circ} \mathrm{C}$. The average annual precipitation is $630 \mathrm{~mm}$ (Dövényi 2010).

Experimental design. - The study area included two habitat-mosaics: a large area of contacting parcels dominated by humid grasslands and a smaller one on a comb of the local microrelief with humid and semi-dry grasslands impacted by forest areas (Fig. 1). Seven sampling sites were established as $50 \times 50 \mathrm{~m}$ sized quadrats. Data collection was carried out from 2002 to 2017. All quadrats were consistently used: 1-2 were extensively grazed and 3-7 were mowed once a year in early June.

Environmental parameters.-Measurements of the main vegetation parameter (average height of the vegetation) were carried out on 3 plots in each sampling site during each orthopteran sampling. The height of the vegetation was measured in $\mathrm{cm}$ with the use of a 30 $\mathrm{cm}$ wide and $100 \mathrm{~cm}$ high white card. The total cover of the vegetation showed only small differences between 90 and 100\% cover, so this parameter was not included in the experiment.

Regarding the 2002-2005 interval, we used public macroclimate data (annual mean temperature and precipitation) from the Hungarian Meteorological Service (www.met.hu), but from 2006 we used detailed daily macroclimate data from the Fertő-Hanság National Park Directorate (coordinates of data collection: $\left.47^{\circ} 42^{\prime} 13.55^{\prime \prime} \mathrm{N}, 17^{\circ} 10^{\prime} 40.43^{\prime \prime} \mathrm{E}\right)$. We used the following derived parameters as potential background variables: seasonal (winter: December-February, spring: March-May, summer: June-August) annual and mean precipitation; seasonal and annual values of mean, minimum and maximum temperature; seasonal and annual values of mean, minimum and maximum humidity; mean of the monthly active and effective thermic amount $\left(10^{\circ} \mathrm{C}\right)$.

Orthoptera._During the study period (2002-2017), sampling of the Orthoptera took place every June, July, August, and September.

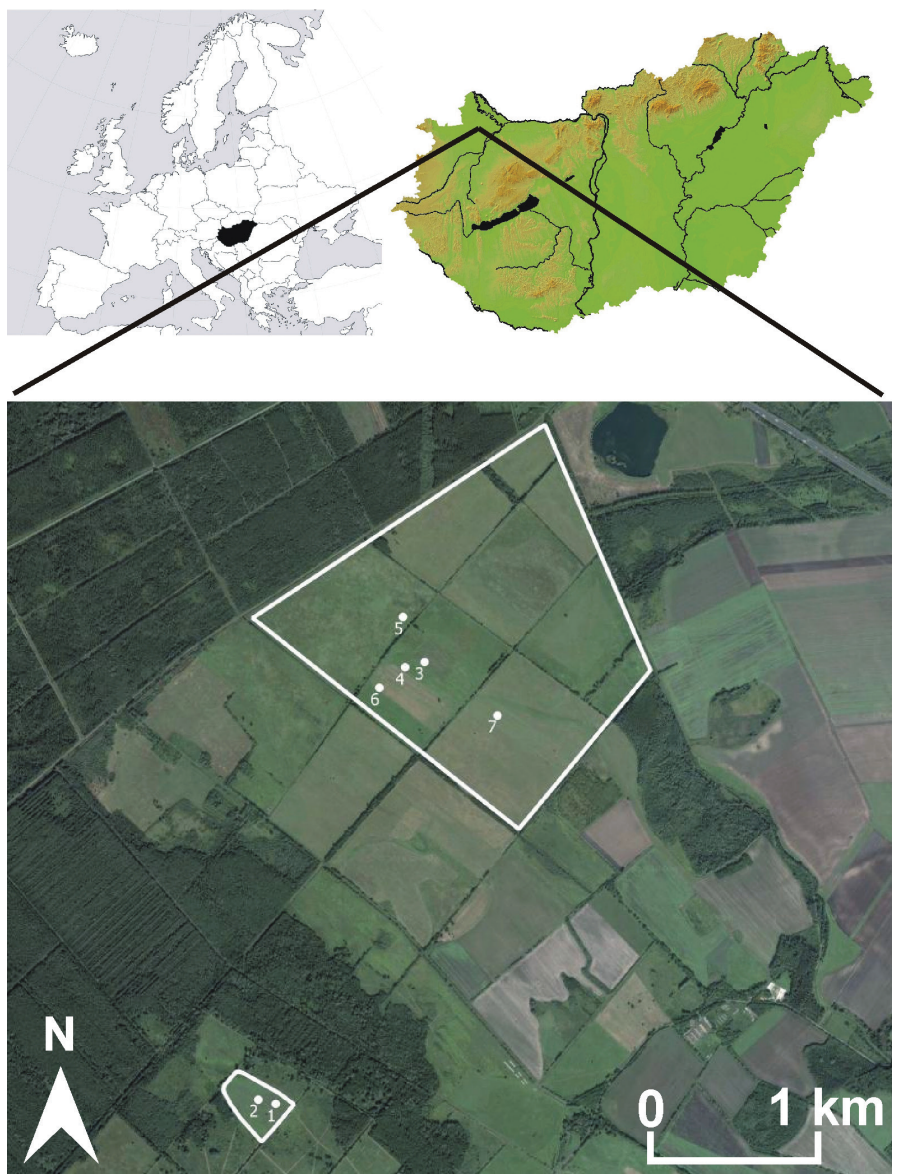

Fig. 1. Location map of the study area in Hungary.

Samplings were carried out by sweep-netting within the $50 \times 50 \mathrm{~m}$ sampling sites (altogether 448 samples). Species abundances were recorded by 300 sweeps per sampling site. Sweep-netted samples were identified to species level following Harz (1969, 1975). Scientific nomenclature follows Cigliano et al. (2017).

The categories defined by Uvarov (1977) and Ingrisch and Köhler (1998) were used for classification of life forms (arbusticole: species found in habitats dominated by shrub-sized items; pratinicole: species found in grasslands of tall grass; graminicole: species found in grasslands of short grass; geophilic: species found in grasslands characterized by a high percentage of bare soil; pseudo-psammophilic: species found in different types of grasslands but usually having a high density in sandy grasslands).

The characterization of the climatic requirements of the species as thermophilic, moderately-thermophilic, mesophilic, moderately-hygrophilic, and hygrophilic were assigned based on Varga (1997), Rácz (1998), and Ingrisch and Köhler (1998).

Statistical analysis. - Samples collected in the same sampling sites in the same year were pooled (the number of pooled samples was 112). The pooled samples were used for calculating assemblage variables and statistical analyses. Shannon diversity, species number, relative abundances of detected species, of life forms, and of species-groups with different climatic requirements were calculated and used as Orthoptera variables in the statistical analyses. The mean values of Orthoptera response variables were calculated for comparison. 
The Mann-Kendall trend test was used to evaluate temporal trends for both the Orthoptera variables and the macroclimate data. Generalized linear models (response variables: parameters of Orthoptera showed statistically significant decreasing or increasing trends; predictor variables: macroclimate data) were performed. Canonical correspondence analysis based on Orthoptera species data and environmental parameters were also compiled. All statistical analyses were performed using the Past 3.14. software package (Hammer et al. 2001).

\section{Results}

Orthoptera species.-Thirty-four Orthoptera species comprising 11,191 individuals were recorded at the sampling sites. The most prevalent species was Bicolorana bicolor with 1,779 individuals (16\%), followed by Chorthippus brunneus with 1,530 individuals (14\%), Roeseliana roeselii with 1,317 individuals (12\%), Pseudochorthippus parallelus with 1,261 individuals (11\%), Conocephalus fuscus with 1,084 individuals (10\%), Chorthippus mollis with 1,042 individuals (9\%), Chorthippus biguttulus with 742 individuals (7\%), Euchorthippus declivus with 392 individuals (4\%), Stenobothrus lineatus with 368 individuals (3\%), Euthystira brachyptera with 330 individuals (3\%), Chrysochraon dispar with 312 individuals (3\%), and Mecostethus parapleurus with 194 individuals (2\%) (see Appendix 1).

Trends in Orthoptera parameters. - During the study a significant decreasing trend in the relative abundance of moderately-hygrophilic species (Fig. 2A), a non-significant increasing in the relative abundance of thermophilic species (Fig. 2B), and a significant increasing trend in the relative abundance of graminicole species (Fig. 2C) were detected. Species richness also showed a significant increase (Fig. 2D). Of the species recorded, the relative abundance of mesophilic Chrysochraon dispar and thermophilic Euchorthippus declivus increased significantly (Fig. 3A, C), while the moderately-hygrophilic Roeseliana roeselii showed a significant decrease (Fig. 3B).

Trends in macroclimate parameters. - A significant increasing trend was seen in the data of annual mean temperature (Fig. 4A); while annual precipitation showed no clear trend (Fig. 4B), mean monthly precipitation showed a non-significant decrease from 2006 to 2017 (Fig. 4C).

Effects of macroclimate parameters.-Based on the results of the generalized linear models, annual mean temperature and annual minimum temperature were found to be significant predictors of the relative abundance of graminicole, pratinicole, and thermophilic species, of the species number, and of the diversity of the assemblages. The increase of annual mean temperature and annual minimum temperature were found to be significant predictors of a higher relative abundance of graminicole thermophilic species, a lower relative abundance of pratinicole species, and higher orthopteran species diversity and species richness (Table 1). Also, the relative abundance of graminicole species and the diversity of the assemblages were positively related to mean temperature in summer. Besides, orthopteran diversity and the relative abundance of moderately thermophilic and thermophilic species were positively related to the means of the monthly active and effective thermic amount $\left(10^{\circ} \mathrm{C}\right)$.

Based on canonical correspondence analysis (CCA) ordination, the relative abundance of graminicole species, thermophilic
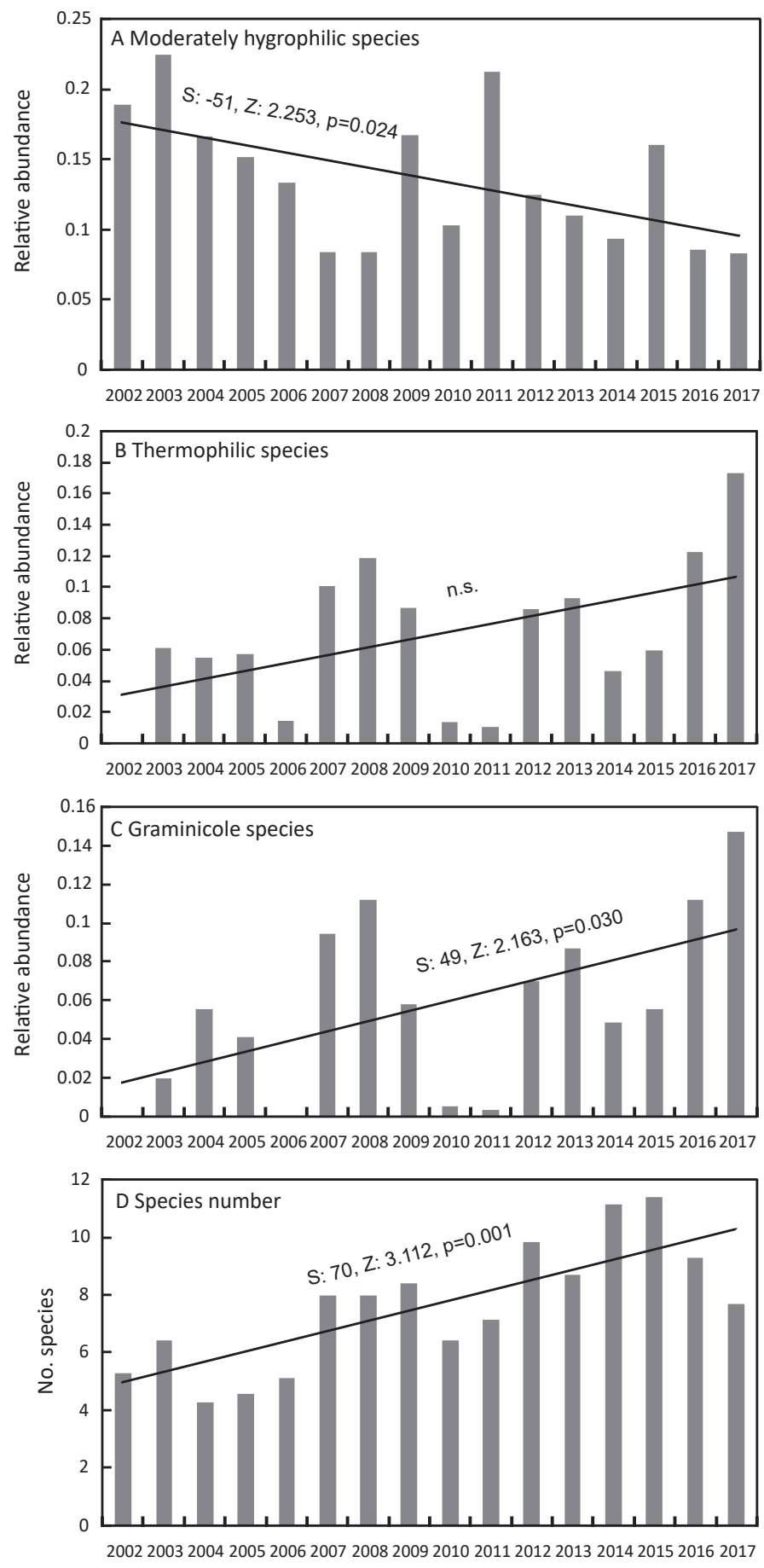

Fig. 2. Decreasing and increasing trends in the relative abundance of some orthopteran parameters (2002-2017). Temporal trends were evaluated by the Mann-Kendall trend test.

species, and Euchorthippus declivus were positively correlated with mean temperature in summer (Fig. 5). The relative abundance of Roeseliana roeselii was negatively correlated with the latter parameter. The relative abundance of pratinicole species and Conocephalus fuscus were positively correlated to high precipitation in spring (Fig. 5). Species richness was affected by annual mean and minimum temperature and also by monthly active and effective thermic amount $\left(10^{\circ} \mathrm{C}\right)$ (Fig. 5). 

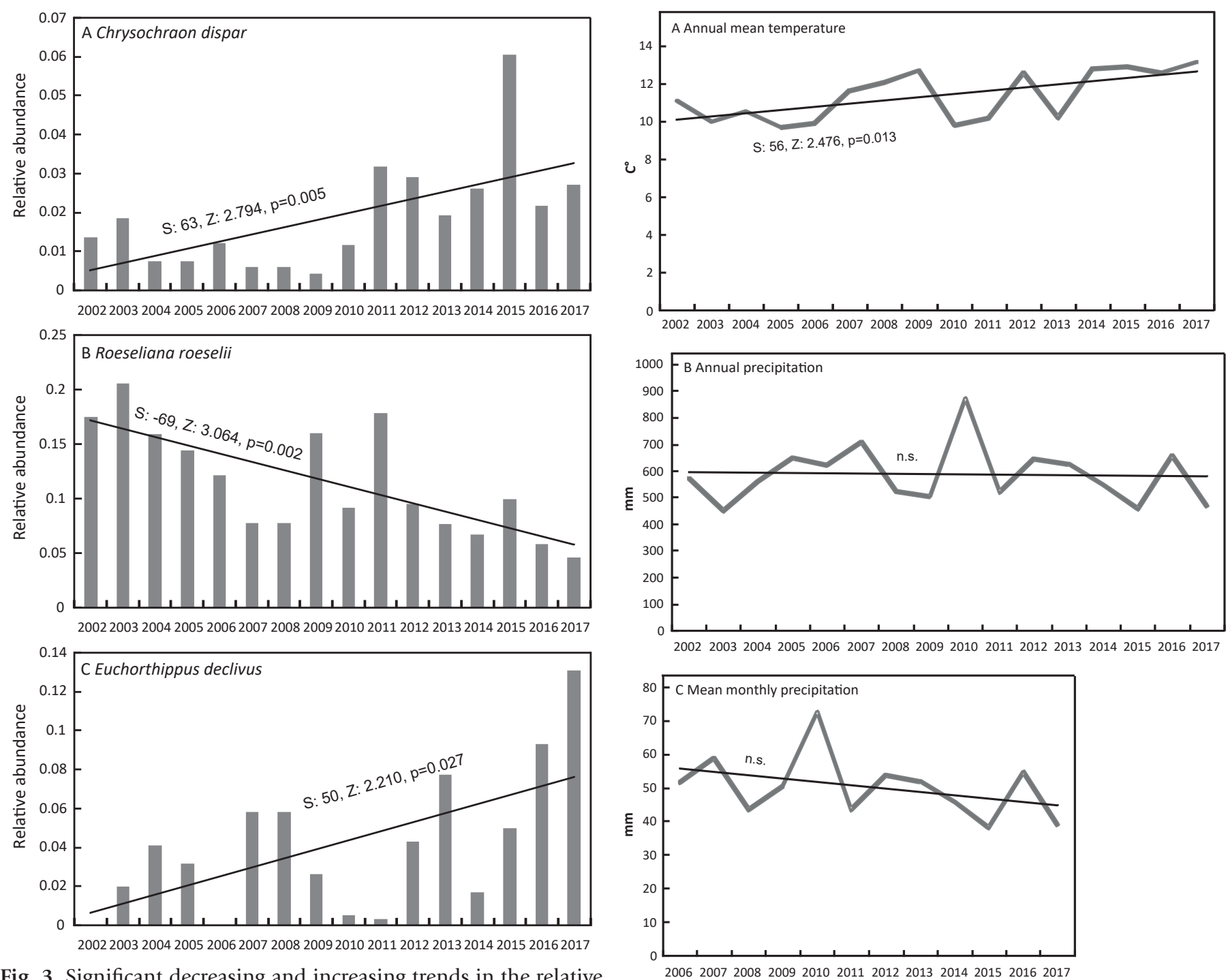

Fig. 3. Significant decreasing and increasing trends in the relative abundance of some characteristic Orthoptera species in the studied grasslands (2002-2017). Temporal trends were evaluated by the Mann-Kendall trend test.

\section{Discussion}

Global warming (Bale et al. 2002), which has a complex effect on insect communities, is an existing phenomenon in Central Europe (Anders et al. 2014). It is well known that species-specific ecological requirements make the orthopterans particularly sensitive to climate change (Wessely et al. 2017). Between 2002 and 2017, the annual average temperature increased significantly in the humid grasslands of the Carpathian Basin that we studied. No trend was identified in annual rainfall. In the grasslands investigated, the relative abundance of moderately hygrophilic orthopteran species decreased significantly, while the relative abundance of thermophilic species increased.

These results suggest that species adapted to cooler climates are more sensitive to climate change (Butterfeld and Coulson 1997). It should be noted that the fluctuation in macroclimate data more than the gradual increase in mean temperature (Fig. 4A) may have a stronger negative impact on certain species in the long run (Easterling et al. 2000). During the study

Fig. 4. Trends in macroclimate parameters on the studied area (2002-2017). Temporal trends were evaluated by the Mann-Kendall trend test.

period, the relative abundance of graminicole species also increased which might be related not only to the macroclimate changes, but also to the eutrophication of the grasslands (Lind et al. 2017).

In our study, the effect of macroclimate change was also detectable at species level. The vertical and horizontal area expansion of thermophilic species as a result of global warming which has been described in several areas (Kočárek et al. 2008, Breitenmoser 2015, Kettermann and Fartmann 2018) was also observed in this study. Over the course of the study, some species were found in the sample areas which were not present in the early years, possibly due to their dry-hot climatic requirements (e.g., Calliptamus italicus, Euchorthippus declivus, Omocestus petraeus, and Platycleis affinis). Of the results related to the change in the local relative abundance of the species, a significant decrease in the relative abundance of the moderately-hygrophilic Roeseliana roeselii is remarkable, although the species is represented in the whole dataset with a large number of specimens. In recent decades, the northward expansion of Roeseliana roeselii and 


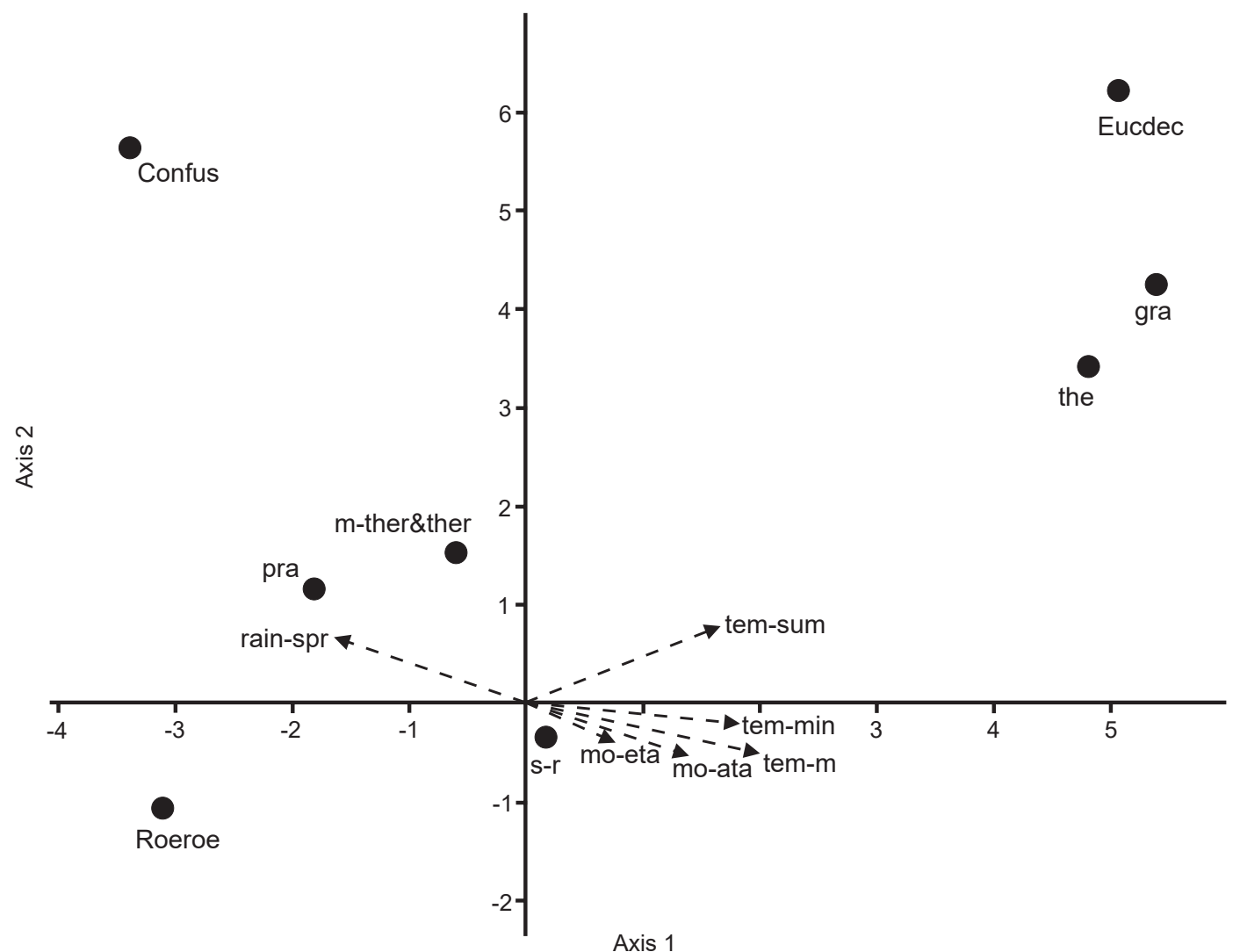

Fig. 5. CCA ordination based on Orthoptera parameters and environmental parameters (Confus: Conocephalus fuscus; Eucdec: Euchorthippus declivus; gra: graminicole species; mo-ata: mean of the monthly active thermic amount $\left(10^{\circ} \mathrm{C}\right)$; mo-eta: mean of the monthly effective thermic amount $\left(10^{\circ} \mathrm{C}\right)$; m-ther\&ther: moderately-thermophilic and thermophilic species; pra: pratinicole species; rain-spr: rainfall in spring; Roeroe: Roeseliana roeselii; s-r: species richness; tem-m: annual mean temperature; tem-min: annual minimum temperature; tem-sum: mean temperature in summer; the: thermophilic species).

Table 1. Significant results of GLM testing of macroclimate effects on Orthoptera assemblages $\left({ }^{*} \mathrm{P}<0.05 ;{ }^{*} \mathrm{P}<0.01 ;{ }^{* *} \mathrm{P}<0.001\right.$; data for the mean of the monthly active and effective thermic amount and precipitation were log transformed).

\begin{tabular}{|c|c|c|c|c|}
\hline Response variable & Predictor variable & Estimate & St.err. & $\mathbf{p}$ \\
\hline Roeseliana roeselii & Mean temp. in summer & -16.634 & 6.146 & $* *$ \\
\hline Euchorthippus declivus & Mean temp. in summer & 16.701 & 6.061 & $* *$ \\
\hline \multirow[t]{3}{*}{ Graminicole species } & Mean temp. in summer & 14.194 & 5.102 & $* *$ \\
\hline & Annual mean temp. & 14.467 & 6.715 & $* *$ \\
\hline & Annual min. temp. & 24.513 & 8.943 & $* *$ \\
\hline \multirow[t]{2}{*}{ Pratinicole species } & Annual mean temp. & -18.041 & 7.436 & $*$ \\
\hline & Annual min. temp. & -28.779 & 8.940 & $* *$ \\
\hline \multirow[t]{6}{*}{ Diversity } & Annual mean temp. & 16.789 & 5.733 & $* *$ \\
\hline & Annual min. temp. & 19.768 & 8.605 & $*$ \\
\hline & $\begin{array}{l}\text { Mean of the monthly active } \\
\text { thermic amount }\left(10^{\circ} \mathrm{C}\right)\end{array}$ & 0.698 & 0.253 & $* *$ \\
\hline & $\begin{array}{l}\text { Mean of the monthly effective } \\
\text { thermic amount }\left(10^{\circ} \mathrm{C}\right)\end{array}$ & 0.932 & 0.344 & ** \\
\hline & Mean temp. in summer & 12.109 & 4.757 & * \\
\hline & Precipitation in spring & -1.844 & 0.867 & * \\
\hline \multirow[t]{2}{*}{ Species number } & Precipitation in spring & -0.052 & 0.025 & * \\
\hline & Annual mean temp. & 0.508 & 0.158 & $* *$ \\
\hline \multirow[t]{2}{*}{ Thermophilic species } & Annual mean temp. & 16.551 & 6.299 & $* *$ \\
\hline & Annual min. temp. & 22.859 & 8.486 & $* *$ \\
\hline \multirow{2}{*}{$\begin{array}{l}\text { Moderately } \\
\text { thermophilic and } \\
\text { thermophilic species }\end{array}$} & $\begin{array}{l}\text { Mean of the monthly active } \\
\text { thermic amount }\left(10^{\circ} \mathrm{C}\right)\end{array}$ & 0.302 & 0.108 & $* *$ \\
\hline & $\begin{array}{l}\text { Mean of the monthly effective } \\
\text { thermic amount }\left(10^{\circ} \mathrm{C}\right)\end{array}$ & 0.411 & 0.145 & $* *$ \\
\hline
\end{tabular}

Conocephalus fuscus, also occurring in the humid grasslands of Central Europe, was recorded in northern and northwestern Europe (Kleukers et al. 1996, Fartmann 2004, Wissmann et al. 2009). On the one hand, this latter phenomenon confirms the fact that the impact of global warming is more intense in areas closer to the poles (Bale et al. 2002). It is not only recent experiences, but also the results explored in the case of climate changes in earlier geologic epochs (Coope 1970), which indicate that insects do not adapt to the changed conditions in the case of climate change, but follow it by changing their areas.

In conclusion, in the Central European humid grasslands studied, the increase in the annual mean temperature most intensively affected negatively the relative abundance of moderately hygrophilic orthopteran species. The expansion of thermophilic species could also be observed within the study area (they occupied habitats that were not previously suitable for them). The number of species and diversity of the local orthopteran assemblages was higher as the annual average temperature increased. From a conservation point of view, this is not necessarily a positive fact. The orthopteran assemblages of humid grasslands in Central Europe are normally characterized by low diversity, due to the dominance of some hygrophilic and moderately hygrophilic species. According to our results, the conservation of the main characteristics of the Central European humid grasslands, under global warming, can only be ensured by adequate land management. 


\section{Suggestions for adequate land management}

Due to the causes of global warming, the following suggestions for adequate local land management of humid grasslands in Central Europe are suggested: (1) Spatial mosaic grassland management by changing the patches abandoned throughout the season every year. (2) Exclusion of grazing or, at the most, only in an extensive manner during autumn. (3) Abandonment of mowing in extremely dry years with a warm spring (except for patches affected by invasive plant species). The above options can result in a mitigating effect of the denser vegetation (Cox and Moore 1980, Schoonhoven et al. 1998), which regulates the microclimate of the humid grasslands.

\section{Acknowledgements}

The authors would like to express their gratitude to the reviewers for their remarks. We are very grateful to Maria Marta Cigliano, Subject Editor of JOR and to Nancy Morris, Editorial Assistant of JOR, for their work with our manuscript.

\section{References}

Anders I, Stagl J, Auer I, Pavlik D (2014) Climate change in Central and Eastern Europe. In: Rannow S, Neubert M (Eds) Managing Protected Areas in Central and Eastern Europe Under Climate Change, Advances in Global Change Research 58, Springer Science+Business Media Dordrecht, 17-30. https://doi.org/10.1007/978-94-007-7960-0_2

Bale JS, Masters GJ, Hodkinson ID, Awmack C, Bezemer TM, Brown VK, Butterfield J, Buse A, Coulson JC, Farrar J, Good JEG, Harrington R, Hartley S, Jones TH, Lindroth RL, Press MC, Symrnioudis I, Watt AD, Whittaker JB (2002) Herbivory in global climate change research: direct effects of rising temperature on insect herbivores. Global Change Biology 8: 1-16. https://doi.org/10.1046/j.13652486.2002.00451.x

Breitenmoser S (2015) Expansion de l'Oedipode automnale Aiolopus strepens (Latreille, 1804) (Orthoptera, Acrididae) dans l'Ouest vaudois. Entomo Helvetica 8: 133-139.

Buri P, Arlettaz R, Humbert JY (2013) Delaying mowing and leaving uncut refuges boosts orthopterans in extensively managed meadows: Evidence drawn from field-scale experimentation. Agriculture, Ecosystems and Environment 181: 22-30. https://doi.org/10.1016/j. agee.2013.09.003

Burton JF (2001) The apparent influence of climatic change on recent changes of range by European insects (Lepidoptera, Orthoptera). In: Reemer M, Helsdingen PJ, Kleukers R MJC (Eds) Proceedings of the $13^{\text {th }}$ International Colloquium of the European Invertebrate Survey, Leiden, 2-5 September 2001, 13-22.

Butterfeld J, Coulson JC (1997) Terrestrial invertebrates and climate change: physiological and life-cycle adaptations. In: Huntley $\mathrm{B}$, Cramer W, Morgan AV, Prentice HC, Allen JRM (Eds) Past and Future Rapid Environmental Change, Springer, Berlin, 401-412. https://doi. org/10.1007/978-3-642-60599-4_31

Cigliano MM, Braun H, Eades DC, Otte D (2017) Orthoptera Species File. Version 5.0/5.0. http://Orthoptera.SpeciesFile.org

Coope GR (1970) Interpretations of Quaternary insect fossils. Annual Review of Entomology15: 97-120. https://doi.org/10.1146/annurev. en.15.010170.000525

Cox CB, Moore PD (1980) Biogeography, an Ecological and Evolutionary Approach. Blackwell, Oxford.

Dövényi Z (Ed.) (2010) Magyarország kistájainak katasztere. [Cadastre of the Hungarian microregions] MTA Földrajztudományi Kutatóintézet, Budapest. [In Hungarian]

Dreux P (1962) Recherches écologiques et biogéographies sur les Orthoptères des Alpes Françaises. Théses presentées a la Faculté de Sciences de L’Université de Paris. Masson \& $C^{\text {ie }}$ Éditeurs, Paris.
Easterling DR, Meehl GA, Parmesan C, Changnon SA, Karl TR, Mearns LO (2000) Climate extremes: observations, modeling, and impacts. Science 289: 2068-2074. https://doi.org/10.1126/science.289.5487.2068

Fartmann T (2004) Hydrochorie und warme Jahre - sind das die Gründe für die Ausbreitung der Langflügeligen Schwertschrecke (Conocephalus fuscus) in Ostbrandenburg? Articulata 19: 75-90.

Fielding DJ, Defoliart LS (2010) Embryonic developmental rates of northern grasshoppers (Orthoptera: Acrididae): Implications for climate change and habitat management. Environmental Entomology 39: 1643-1651. https://doi.org/10.1603/EN09356

Gardiner T (2009) Macropterism of Roesel's bushcricket Metrioptera roeselii in relation to climate change and landscape structure in eastern England. Journal of Orthoptera Research 18: 95-102. https://doi. org/10.1665/034.018.0110

Gardiner T, Hassall M (2009) Does micro-climate affect grasshopper populations after cutting of hay in improved grassland? Journal of Insect Conservation 13: 97-102. https://doi.org/10.1007/s10841-0079129-y

Guido M, Chemini C (2000) Response of Orthoptera assemblage composition to land-use in the southern Alps of Italy. Mitteilungen der Schweizerischen Entomologischen Gesellschaft 73: 353-367.

Hammer Ø, Harper DAT, Ryan PD (2001) PAST: Paleontological Statistics Software Package for Education and Data Analysis. Palaeontologia Electronica 4: 1-9.

Harz K (1969) Die Orthopteren Europas - The Orthoptera of Europe I. Series Ent. 5, The Hague. https://doi.org/10.1007/978-94-017-2511-8

Harz K (1975) Die Orthopteren Europas / The Orthoptera of Europe II. Series Ent. 11, The Hague. https://doi.org/10.1007/978-94-010-1947-7

Holuša J, Kočárek P, Marhoul P (2007) First sightings of Ruspolia nitidula (Orthoptera: Tettigoniidae) and Mecostethus parapleurus (Orthoptera: Acrididae) after fifty years in the Czech Republic. Articulata 22: 47-51. Ingrisch S, Köhler G (1998) Die Heuschrecken Mitteleuropas. Die Neue Brehm-Bücherei Bd. 629, Westarp Wissenschaften, Magdeburg.

Kenyeres Z, Cservenka J (2014) Effects of climate change and various grassland management practices on grasshopper (Orthoptera) assemblages. Advances in Ecology 2014: e601813. https://doi. org/10.1155/2014/601813

Kenyeres Z, Takács G, Bauer N (2018) Effects of climatic factors on yearly population sizes of Isophya costata (Orthoptera). North-Western Journal of Zoology 14: 13-16.

Kettermann M, Fartmann T (2018) Auswirkungen des globalen Wandels auf Heuschrecken - Besiedlung von Steinbrüchen der Westfälischen Bucht (NW-Deutschland) durch die Blauflügelige Sandschrecke. Naturschutz und Landschaftsplanung 50: 23-29.

Kiritani K (2006) Predicting impacts of global warming on population dynamics and distribution of arthropods in Japan. Population Ecology 48: 5-12. https://doi.org/10.1007/s10144-005-0225-0

Kleukers RMJC, Decleer K, Haes ECM, Kolshorn P, Thomas B (1996) The recent expansion of Conocephalus discolor (Thunberg) (Orthoptera: Tettigoniidae) in western Europe. Entomologist's Gazette 47: 37-49.

Kočárek P, Holuša J, Vlk R, Marhoul P, Zuna-Kratky T (2008) Recent expansions of bush-crickets Phaneroptera falcata and Phaneroptera nana (Orthoptera: Tettigoniidae) in the Czech Republic. Articulata 23: 67-75.

Laws AN, Belovsky GE (2010) How will species respond to climate change? Examining the effects of temperature and population density on an herbivorous insect. Environmental Entomology 39: 312-319. https:// doi.org/10.1603/EN09294

Lightfoot DC (2006) Climate Change and Rangeland Insects. Beyond Boxes and Arrows, A Workshop on Climate Change and Rangeland Management, Jan. 25-26, 2006, San Carlos, Arizona.

Lind EM, La Pierre KJ, Seabloom EW, Alberti J, Iribarne O, Firn J, Gruner DS, Kay AD, Pascal J, Wright JP, Yang L, Borer ET (2017) Increased grassland arthropod production with mammalian herbivory and eutrophication: a test of mediation pathways. Ecology 98: 3022-3033. https://doi.org/10.1002/ecy.2029

Menéndez R (2007) How are insects responding to global warming? Tijdschrift voor Entomologie 150: 355-365. 
O'Neill BF, Zangerl AR, Delucia EH, Berenbaum MR (2008) Longevity and fecundity of Japanese beetle (Popillia japonica) on foliage grown under elevated carbon dioxide. Environmental Entomology 37: 601-607. https://doi.org/10.1603/0046-225X(2008)37[601:LAFO] B]2.0.CO;2

Rácz I (1998) Biogeographical survey of the Orthoptera fauna in central part of the Carpathian Basin (Hungary): Fauna types and community types. Articulata 13: 53-69.

Rácz I, Szilágyi G, Molnár A (1994) Sáskajárás a Hortobágyon. [Locust gradation on the Hortobágy.] II. Kelet-Magyarországi erdő, vad- és halgazdálkodási, természetvédelmi konferencia, Debrecen, 1994. XI. 5-6., 372-380.

Ryrholm N (2001) Global warming and the change of butterfly distributions: a new opportunity for species diversity or a severe threat (Lepidoptera)? In: Reemer M, Helsdingen PJ, Kleukers RMJC (Eds) Proceedings of the $13^{\text {th }}$ International Colloquium of the European Invertebrate Survey, Leiden, 2-5 September 2001, 7-12.

Schoonhoven LM, Jermy T, van Loon JJA (1998) Insect-Plant Biology: From Physiology to Evolution. Chapman \& Hall, London. https:// doi.org/10.1007/978-1-4899-3200-6

Squitier JM, Capinera JL (2002) Habitat associations of Florida grasshoppers (Orthoptera: Acrididae). Florida Entomologist 85: 235244. https://doi.org/10.1653/0015-4040(2002)085[0235:HAOFG O]2.0.CO;2
Szabó B, Nagy B, Szentkirályi F (2014) Egyenesszárnyú rovarfajok (Orthoptera) lárvakeléskezdeteinekhosszú távú trendjei (1958-2009) az éghajlatváltozás következményeként Magyarországon. Állattani Közlemények 99: 45-59.

Uvarov BP (1931) Insects and climate. Transactions of the Entomological Society. London, 79: 1-247.

Uvarov BP (1977) Grasshoppers and Locusts, Vol. II. Centre for Overseas Pest Research, London.

Varga Z (1997) Trockenrasen im pannonischen Raum: Zusammenhang der physiognomischen Struktur und der florischtischen Komposition mit den Insektenzönosen. Phytocoenologia 27: 509-571. https://doi. org/10.1127/phyto/27/1997/509

Wessely J, Hülber K, Gattringer A, Kuttner M, Moser D, Rabitsch W, Schindler S, Dullinger S, Essl F (2017) Habitat-based conservation strategies cannot compensate for climate-change-induced range loss. Nature Climate Change 7: 823-827. https://doi.org/10.1038/nclimate3414

Wingerden WKRE, Kreveld AR, Bongers W (1992) Analysis of species composition and abundance of grasshoppers (Orth., Acrididae) in natural and fertilized grasslands. Journal of Applied Entomology 113: 138152. https://doi.org/10.1111/j.1439-0418.1992.tb00647.x

Wissmann J, Schielzeth H, Fartmann T (2009) Landscape-scale expansion of Roesel's bush-cricket Metrioptera roeselii at the north-western range limit in Central Europe (Orthoptera: Tettigoniidae). Entomologia Generalis 31: 317-326. https://doi.org/10.1127/entom.gen/31/2008/317

\section{Appendix 1}

Species composition and abundance of the samples pooled per year (LF: life form; EF: ecotype form; arbu: arbusticole; geo: geophilic; gra: graminicole; pra: pratinicole; psps: pseudo-psammophilic; hyg: hygrophilic; mes: mesophilic; m-hyg: moderately-hygrophilic; m-ther: moderately-thermophilic; ther: thermophilic).

\begin{tabular}{|c|c|c|c|c|c|c|c|c|c|c|c|c|c|c|c|c|c|c|}
\hline Taxon & LF & EF & 2002 & 2003 & 2004 & 2005 & 2006 & 2007 & 2008 & 2009 & 2010 & 2011 & 2012 & 2013 & 2014 & 2015 & 2016 & 2017 \\
\hline Bicolorana bicolor (Philippi, 1830) & pra & m-ther & 34 & 159 & 138 & 112 & 157 & 94 & 94 & 71 & 138 & 192 & 128 & 31 & 24 & 158 & 147 & 102 \\
\hline Chorthippus brunneus (Thunberg, 1815) & pra & m-ther & 21 & 130 & 24 & 45 & 50 & 100 & 91 & 96 & 336 & 72 & 206 & 47 & 112 & 104 & 62 & 34 \\
\hline Roeseliana roeselii (Hagenbach, 1822) & pra & m-hyg & 46 & 176 & 37 & 44 & 60 & 69 & 70 & 126 & 96 & 174 & 82 & 67 & 64 & 102 & 70 & 34 \\
\hline Pseudochorthippus parallelus (Zetterstedt, 1821) & pra & mes & 45 & 8 & 18 & 17 & 104 & 58 & 58 & 51 & 144 & 106 & 116 & 120 & 122 & 114 & 152 & 28 \\
\hline Conocephalus fuscus (Fabricius, 1793) & pra & hyg & 21 & 60 & 26 & 29 & 24 & 50 & 51 & 52 & 152 & 134 & 28 & 89 & 134 & 130 & 58 & 46 \\
\hline Chorthippus mollis (Charpentier, 1825) & pra & mes & 6 & 56 & 0 & 0 & 72 & 50 & 64 & 102 & 236 & 31 & 108 & 75 & 72 & 66 & 64 & 40 \\
\hline Chorthippus biguttulus (Linnaeus, 1758) & pra & m-ther & 4 & 61 & 0 & 0 & 22 & 59 & 60 & 58 & 47 & 64 & 96 & 91 & 78 & 49 & 20 & 33 \\
\hline Euchorthippus declivus (Brisout de Barneville, 1848) & gra & ther & 0 & 20 & 18 & 14 & 0 & 28 & 28 & 20 & 6 & 4 & 42 & 52 & 14 & 36 & 64 & 46 \\
\hline Stenobothrus lineatus (Panzer, 1796) & pra & m-ther & 2 & 22 & 27 & 26 & 0 & 21 & 22 & 6 & 12 & 47 & 24 & 38 & 60 & 15 & 40 & 6 \\
\hline Euthystira brachyptera (Ocskay, 1826) & pra & mes & 11 & 42 & 0 & 0 & 25 & 20 & 19 & 52 & 0 & 50 & 22 & 20 & 30 & 34 & 5 & 0 \\
\hline Chrysochraon dispar (Germar, 1834) & pra & m-hyg & 5 & 24 & 3 & 2 & 9 & 6 & 5 & 4 & 13 & 46 & 27 & 18 & 36 & 68 & 26 & 20 \\
\hline Mecostethus parapleurus (Hagenbach, 1822) & pra & hyg & 7 & 0 & 0 & 0 & 0 & 0 & 0 & 0 & 0 & 0 & 5 & 0 & 16 & 47 & 64 & 55 \\
\hline Chorthippus dorsatus (Zetterstedt, 1821) & pra & mes & 12 & 8 & 0 & 8 & 0 & 0 & 0 & 14 & 0 & 0 & 8 & 13 & 28 & 25 & 8 & 12 \\
\hline Decticus verrucivorus (Linnaeus, 1785) & pra & mes & 6 & 0 & 0 & 0 & 2 & 3 & 2 & 9 & 8 & 13 & 8 & 19 & 2 & 8 & 9 & 10 \\
\hline Tettigonia viridissima Linnaeus, 1758 & arbu & mes & 0 & 0 & 8 & 12 & 14 & 12 & 11 & 6 & 2 & 7 & 0 & 0 & 8 & 5 & 4 & 0 \\
\hline Calliptamus italicus (Linnaeus, 1758) & gra & ther & 0 & 0 & 0 & 0 & 0 & 15 & 14 & 9 & 0 & 0 & 2 & 6 & 17 & 4 & 0 & 11 \\
\hline Conocephalus dorsalis (Latreille, 1804) & pra & hyg & 0 & 0 & 6 & 2 & 0 & 0 & 0 & 0 & 12 & 11 & 4 & 15 & 16 & 2 & 1 & 0 \\
\hline Omocestus petraeus (Brisout de Barneville, 1856) & gra & ther & 0 & 0 & 7 & 3 & 0 & 0 & 6 & 13 & 0 & 0 & 21 & 0 & 0 & 0 & 11 & 0 \\
\hline Phaneroptera falcata (Poda, 1761) & arbu & ther & 0 & 6 & 0 & 0 & 4 & 3 & 1 & 21 & 10 & 0 & 11 & 0 & 0 & 0 & 0 & 0 \\
\hline Omocestus haemorrhoidalis (Charpentier, 1825) & pra & ther & 0 & 21 & 0 & 6 & 0 & 0 & 0 & 0 & 0 & 9 & 5 & 3 & 0 & 2 & 7 & 3 \\
\hline Pseudochorthippus montanus (Charpentier, 1825) & pra & hyg & 13 & 21 & 0 & 0 & 0 & 0 & 0 & 0 & 0 & 0 & 0 & 0 & 0 & 0 & 0 & 8 \\
\hline Tetrix subulata (Linnaeus, 1758) & geo & hyg & 0 & 0 & 0 & 0 & 0 & 0 & 0 & 0 & 31 & 0 & 3 & 0 & 0 & 0 & 0 & 0 \\
\hline Ruspolia nitidula (Scopoli, 1786) & pra & m-hyg & 0 & 0 & 0 & 0 & 0 & 0 & 0 & 3 & 0 & 2 & 0 & 11 & 0 & 0 & 3 & 5 \\
\hline Chorthippus oschei Helversen, 1986 & pra & mes & 10 & 6 & 0 & 0 & 0 & 0 & 0 & 0 & 0 & 0 & 0 & 0 & 0 & 0 & 0 & 0 \\
\hline Omocestus rufipes (Zetterstedt, 1821) & pra & mes & 0 & 0 & 0 & 0 & 0 & 5 & 0 & 0 & 0 & 0 & 5 & 0 & 0 & 0 & 6 & 0 \\
\hline Chorthippus dichrous (Eversman, 1859) & pra & mes & 0 & 0 & 0 & 0 & 0 & 0 & 0 & 0 & 0 & 0 & 0 & 0 & 6 & 0 & 4 & 2 \\
\hline Tetrix tenuicornis (Schalberg, 1893) & pra & ther & 0 & 12 & 0 & 0 & 0 & 0 & 0 & 0 & 0 & 0 & 0 & 0 & 0 & 0 & 0 & 0 \\
\hline Oecanthus pellucens (Scopoli, 1763) & pra & m-ther & 0 & 0 & 3 & 5 & 0 & 0 & 0 & 0 & 0 & 0 & 0 & 0 & 0 & 0 & 0 & 0 \\
\hline Leptophyes albovittata (Kollar, 1833) & arbu & ther & 0 & 0 & 0 & 0 & 3 & 0 & 0 & 0 & 0 & 0 & 0 & 0 & 1 & 2 & 0 & 0 \\
\hline Stethophyma grossum (Linnaeus, 1758) & pra & hyg & 3 & 5 & 0 & 0 & 0 & 0 & 0 & 0 & 0 & 0 & 0 & 0 & 0 & 0 & 0 & 0 \\
\hline Aiolopus thalassinus (Fabricius, 1781) & gra & m-ther & 0 & 0 & 0 & 0 & 0 & 0 & 0 & 0 & 0 & 0 & 0 & 0 & 6 & 0 & 0 & 0 \\
\hline Stenobothrus nigromaculatus (Herrich-Schäffer, 1840) & gra & ther & 0 & 0 & 0 & 0 & 0 & 0 & 0 & 0 & 0 & 0 & 3 & 0 & 0 & 0 & 0 & 0 \\
\hline Platycleis grisea (Fabricius, 1781) & pra & ther & 0 & 0 & 0 & 0 & 0 & 0 & 0 & 0 & 0 & 0 & 0 & 0 & 3 & 0 & 2 & 0 \\
\hline Platycleis affinis Fieber, 1853 & psps & ther & 0 & 0 & 0 & 0 & 0 & 0 & 0 & 0 & 3 & 0 & 0 & 0 & 0 & 0 & 0 & 1 \\
\hline
\end{tabular}

